\title{
Evaluasi Luaran Klinis Terapi Antibiotika pada Pasien Anak Rawat Inap Dengan Infeksi Saluran Kemih di RSUP Dr. Sardjito Yogyakarta
}

\author{
Evaluation of Clinical Outcomes of Antibiotic Therapy in Pediatric Inpatients with \\ Urinary Tract Infections in RSUP Dr. Sardjito Yogyakarta
}

\author{
Widya Adhitama1, Ika Puspitasari ${ }^{2 *}$, Ida Safitri Laksanawati ${ }^{3}$ \\ ${ }_{1}$ Mahasiswa Magister Farmasi Klinik, Fakultas Farmasi, Universitas Gadjah Mada \\ 2 Departemen Farmakologi dan Farmasi Klinik: Fakultas Farmasi, Universitas Gadjah Mada \\ 3 Divisi Infeksi dan Tropis, Departemen Ilmu Kesehatan Anak, Fakultas Kedokteran UGM / RSUP \\ Dr. Sardjito, Yogyakarta \\ Corresponding author: Ika Puspita Sari: Email: ika.puspitasari@gmail.com
}

Submitted: 16-08-2019 Revised:23-08-2019 Accepted:03-09-2019

\begin{abstract}
ABSTRAK
Infeksi Saluran Kemih (ISK) merupakan penyakit infeksi yang sering terjadi pada anak selain infeksi saluran nafas atas dan diare di negara berkembang. Salah satu terapi yang diberikan adalah antibiotik, pemilihan antibiotik harus didasarkan pola resistensi bakteri lokal. Tujuan penelitian ini untuk menilai hubungan rasionalitas antibiotik empiris terhadap luaran klinis pasien anak rawat inap dengan ISK di Rumah Sakit dr. Sardjito Yogyakarta. Penelitian ini merupakan penelitian observasional menggunakan rancangan deskriptifanalitik dengan desain cohort retrospektif. Subyek penelitian adalah pasien anak rawat inap dengan ISK di Rumah Sakit dr. Sardjito Yogyakarta periode 1 Januari 2016 - 31 Desember 2018. Jumlah pasien yang memenuhi kriteria inklusi dan eksklusi sebanyak 63 pasien dengan 70 regimen antibiotik. Rasionalitas penggunaan antibiotik empiris dievaluasi menggunakan metode Gyssens. Hasil dari penelitian ini menunjukkan antibiotik empiris yang rasional yaitu sebesar 84,3\% (59 regimen), dan yang tidak rasional sebesar 15,7\% (11 regimen). Pada penggunaan antibiotik yang rasional dan memberikan luaran klinis membaik sebesar 82,9\%, dan dianalisis dengan uji Fisher menunjukkan adanya hubungan yang signifikan antara rasionalitas antibiotik empiris terhadap luaran klinis pasien anak ISK dengan nilai $\mathrm{p}=0,011$. Gambaran pola bakteri pada pasien ISK anak yaitu bakteri yang menginfeksi terbesar dari bakteri gram negatif $(81,97 \%)$ dan bakteri gram positif sebesar $18,03 \%$. Kata kunci: Infeksi Saluran Kemih; Antibiotik Empiris; Luaran klinis
\end{abstract}

\begin{abstract}
Urinary Tract Infection (UTI) is one of the most common infection diseases that occurs in children besides upper respiratory tract infection and diarrhea in developing countries. The therapy for UTI is by using antibiotics, where the selection of antibiotics therapy has to be based on the pattern of local bacteria's resistance. The objective of this study were to assess the correlation between antibiotic's rationality and the clinical outcome of UTI in pediatrics from the used of empiric antibiotic for inpatient care pediatrics with UTI at dr. Sardjito Yogyakarta's Hospital. The method in this study was observational descripted-analytic with retrospective cohort design. The subject of this study was the inpatient care pediatrics with UTI at Dr. Sardjito Yogyakarta's hospital from January 2016-Desember 2018. There were 63 patients in this study with 70 regimen of antibiotic. The results of this study indicate that rational used of empiric antibiotics according to Gyssens's method are at $84.3 \%$ ( 59 regimen), and irrational at $15.7 \%$ (11 regimen). The rational used of empiric antibiotics with good clinical outcome was 82,9\% (59 regimen). Based on the analysis of Fisher test, there was a significant correlation between the rationality of antibiotic used and the clinical outcome with p-value 0.011 .
\end{abstract}

Keywords: Urinary Tract Infection; Empiric Antibiotics; Clinical Outcome

\section{PENDAHULUAN}

Infeksi Saluran Kemih (ISK) berdasarkan konsensus IDAI merupakan salah satu penyakit infeksi yang sering terjadi pada anak selain penyakit infeksi lain seperti infeksi saluran nafas atas dan diare. Infeksi saluran kemih juga dapat diartikan sebagai suatu pertumbuhan dan perkembangbiakan mikroba atau kuman di dalam saluran kemih dalam jumlah yang bermakna (Pardede dkk., 2011).

Studi di Amerika menyatakan bahwa perbandingan prevalensi anak-anak yang mengalami ISK pada anak perempuan sebesar 14\% dan anak laki-laki sebesar 1\% (Newman dkk., 2013). Rumah Sakit Cipto Mangunkusumo Jakarta dalam periode 3 tahun (1993-1995) 
didapatkan 212 kasus ISK, dan rata-rata 70 kasus baru setiap tahunnya (Pardede dkk., 2011).

Mikroorganisme yang paling umum menyebabkan infeksi saluran kemih sejauh ini adalah E. coli yang diperkirakan bertanggung jawab terhadap 85\% kasus infeksi, dan 5-15\% disebabkan oleh bakteri lain seperti Staphylococcus, Klebsiella pneumoniae, spesies Proteus dan Enterococcus spp. (Coyle dan Prince, 2008). Gejala yang paling sering terjadi adalah demam. Gejala lain yang dialami oleh anak-anak yang mengalami ISK yaitu nyeri perut, disuria, poliuria dan hematuria (World Health Organization, 2013).

Secara umum anak dengan ISK simpleks dimana kondisi klinis baik dapat diterapi dengan antibiotik oral. Terapi antibiotik intravena diberikan pada kondisi infeksi sedang sampai berat dan tidak dapat menerima asupan oral (World Health Organization, 2013). Berdasarkan pedoman pelayanan kesehatan anak di rumah sakit (2009) menyatakan bahwa sebelum adanya hasil biakan urin dan uji kepekaan, maka antibiotik empirik diberikan selama 7-10 hari untuk eradikasi infeksi akut.

Terapi antibiotik empirik dipilih berdasarkan pada pola resistensi kuman lokal. Antibiotik spektrum luas direkomendasikan untuk pasien anak dengan ISK. Antibiotik lini terapi pertama seperti amoksisilin, kotrimoksazol, sefalosporin (contoh: sefiksim) (Chang dan Shortliffe, 2006). Pemilihan terapi antibiotik harus didasarkan pada pola resistensi kuman lokal. American Academy of Pediatrics (AAP) merekomendasikan untuk terapi antibiotik seperti Nitrofurantoin tidak dapat digunakan, pertimbangan lain dalam pemilihan antibiotik yaitu adanya masalah peningkatan pertumbuhan frekuensi infeksi dengan ESBL (Extended-spectrum beta lactamase) yang dilaporkan lebih dari 20\% memproduksi patogen dan tingkat kejadian lebih sering pada anak-anak (Okarska-Napierała dkk., 2017). Resistensi antibiotik menjadi permasalahan dari WHO secara global. Penggunaan antibiotik yang tidak perlu atau berlebihan akan memicu terjadinya resistensi dan multipel resistensi terhadap bakteri tertentu yang akan menyebar melalui infeksi silang. Resistensi antibiotik tidak dapat dihilangkan, tetapi dapat diperlambat melalui penggunaan antibiotik yang bijak (Kementrian Kesehatan Republik Indonesia, 2011).
Penggunaan antibiotik yang terkendali dan rasional dapat mencegah munculnya resistensi antimikroba (Kementerian Kesehatan Republik Indonesia, 2011). Oleh karenanya, perlu dilakukan suatu penelitian mengenai evaluasi penggunaan terapi antibiotik empiris ISK pada anak terhadap luaran klinis pasien dan untuk mengetahui pola antibiogram pada pasien anak dengan ISK di RSUP Dr. Sardjito Yogyakarta.

\section{METODOLOGI}

Subyek penelitian adalah pasien anak di rawat inap RSUP Dr. Sardjito Yogyakarta dengan diagnosis utama Infeksi Saluran Kemih pada periode 1 Januari 2016 sampai dengan 31 Desember 2018. Penelitian ini menggunakan desain kohort retrospektif dengan rancangan deskriptif analitik dan pengambilan data berdasarkan rekam medik pasien anak dengan diagnosis utama ISK.

Kriteria inklusi pada penelitian ini adalah pasien anak rawat inap umur 0 - 18 tahun dengan diagnosis utama ISK di RSUP Dr. Sardjito Yogyakarta selama periode Januari 2016 Desember 2018, mendapatkan terapi antibiotik empiris dan memiliki data rekam medis yang lengkap. Adapun yang menjadi kriteria eksklusi yaitu pasien anak yang pulang dengan cara pulang paksa atau atas permintaan sendiri atau meninggal dunia.

Evaluasi rasionalitas penggunaan antibiotik pada penelitian ini dengan menggunakan metode diagram alur Gyssens yang merupakan analisa kualitatif antibiotik sesuai rekomendasi dari Kementerian Kesehatan RI tahun 2015 tentang program pengendalian resistensi antimikroba di rumah sakit. Analisa Gyssens akan memberikan hasil sebagai berikut, antibiotik dikategorikan rasional atau tepat penggunaannya apabila masuk kategori 0 dan antibiotik yang tidak rasional atau tidak tepat penggunaannya jika masuk dalam kategori I - VI. Penilaian kerasionalan penggunaan antibiotik dan ketepatan dosis dilihat berdasarkan Konsensus Infeksi Saluran Kemih Pada Anak (Pardede dkk., 2011), Drug Information Handbook 24th edition (Burke dkk., 2015), European Association of Urology (Grabe, 2015). Penggunaan antibiotik yang dievaluasi merupakan antibiotik empiris yang diberikan pada penanganan ISK di ruang perawatan sebelum pasien dilakukan kultur sensitivitas maupun ketika pasien sudah 
Widya Adhitama, et al

Tabel I. Karakteristik pasien ISK anak di RSUP Dr. Sardjito Yogyakarta periode Januari 2016 - Desember 2018

\begin{tabular}{lcc}
\hline Karakteristik & Jumlah (n=63) & Persentase (\%) \\
\hline Usia (tahun) & 57 & \\
$0-11$ & 6 & 90,5 \\
$2-18$ & & 9,5 \\
Jenis kelamin & 25 & 39,7 \\
$\quad$ Laki-laki & 38 & 60,3 \\
$\quad$ Perempuan & & 60,3 \\
Lama pasien dirawat & 38 & 39,7 \\
2-7 hari & 25 & 93,6 \\
> hari & & 6,4 \\
Penyakit penyerta & 59 & \\
Ada & 4 & 58,7 \\
$\quad$ Tidak ada & & 41,3 \\
Status gizi & 37 & \\
Baik & 26 & \\
Buruk & & \\
\hline
\end{tabular}

Tabel II. Frekuensi Komorbiditas Berdasarkan Pediatric Comorbidity Index (PCI)

\begin{tabular}{lcc}
\hline Skor PCI & Jumlah (n=63) & Persentase (\%) \\
\hline $0-2$ & 53 & 84,1 \\
$3-5$ & 8 & 12,7 \\
$\geq 6$ & 2 & 3,2 \\
\hline
\end{tabular}

dilakukan kultur sensitivitas tetapi masih menunggu hasil kultur tersebut keluar.

Analisis data dilakukan dalam dua tahap yaitu analisis deskriptif dan analisis analitik. Uji hipotesis pada penelitian ini dilakukan dengan uji Chi-square, namun apabila tidak memenuhi syarat uji Chi-square maka akan digunakan uji Fisher sebagai alternatifnya. Analisis statistik pada penelitian ini menggunakan interval kepercayaan (CI) sebesar 95\% $(\alpha=5)$ (Dahlan, 2016). Uji Kruskall Wallis digunakan untuk analisis pengaruh hubungan indeks komorbid terhadap luaran klinis pasien.

\section{HASIL DAN PEMBAHASAN}

Penelitian yang dilakukan selama bulan Mei - Juni 2019 pada data pasien anak rawat inap dengan infeksi saluran kemih di RSUP Dr. Sardjito Yogyakarta periode Januari 2016 Desember 2018 memperoleh data sebanyak 63 pasien dengan 70 regimen antibiotik. Berdasarkan data karakteristik pasien (tabel I), infeksi saluran kemih pada anak banyak terjadi pada perempuan yaitu 38 kasus $(60,3 \%)$ dan golongan umur terbanyak yaitu 0-11 tahun dengan 57 kasus $(90,5 \%)$. Infeksi saluran kemih banyak dialami oleh perempuan karena perempuan memiliki panjang uretra yang lebih pendek dibandingkan dengan laki-laki sehingga populasi perempuan memiliki resiko yang lebih besar untuk terinfeksi bakteri di perineum ke vesika urinaria (Gunduz dan Altun, 2018).

Status gizi merupakan salah satu faktor resiko yang dapat berpengaruh pada kejadian ISK, yaitu pada kondisi malnutrisi secara tidak langsung akan mengakibatkan tubuh mengalami penurunan fungsi imun sehingga akan mudah atau rentan terkena infeksi (Triasta, 2016). Penelitian ini mendapatkan hasil sebagian besar anak yang mengalami ISK memiliki status gizi yang baik yaitu sebesar 58,73\% (37 pasien). Hasil dari penelitian ini tidak sejalan dengan penelitian sebelumnya yang hasilnya bahwa status gizi berhubungan dengan infeksi saluran kemih, dimana frekuensi kejadian ISK pada anak gizi kurang lebih tinggi dibanding dengan gizi baik (Rosli, 2008). Perbedaan hasil tersebut bisa dikarenakan banyak faktor lain yang mempengaruhinya, seperti misalnya faktor kebersihan pribadi anak dan kebersihan lingkungan berpengaruh terhadap ISK.

Hasil penelitian ini menunjukkan sebanyak $93,5 \%$ pasien memiliki penyakit penyerta. Menurut Torres (2019), dengan 
Tabel III. Hasil analisa karakteristik terhadap luaran klinis

\begin{tabular}{|c|c|c|c|}
\hline \multirow{2}{*}{ Karakteristik } & \multicolumn{2}{|c|}{ Luaran klinis } & \multirow{2}{*}{ Nilai p } \\
\hline & Membaik & Belum membaik & \\
\hline \multicolumn{4}{|l|}{ Usia } \\
\hline $0-11$ tahun & 54 & 3 & \multirow[t]{2}{*}{0,337} \\
\hline $12-18$ tahun & 5 & 1 & \\
\hline \multicolumn{4}{|l|}{ Jenis kelamin } \\
\hline Laki-laki & 24 & 1 & \multirow[t]{2}{*}{1,000} \\
\hline Perempuan & 35 & 3 & \\
\hline \multicolumn{4}{|l|}{ Status gizi } \\
\hline Baik & 34 & 3 & \multirow[t]{2}{*}{0,637} \\
\hline Buruk & 35 & 1 & \\
\hline \multicolumn{4}{|c|}{ Lama perawatan } \\
\hline $2-7$ hari & 35 & 3 & \multirow[t]{2}{*}{1,000} \\
\hline$>7$ hari & 24 & 1 & \\
\hline
\end{tabular}

adanya peningkatan skor komorbiditas maka akan berdampak pada resiko lama perawatan pasien, peningkatan biaya rawat inap pasien, serta penurunan kualitas hidup pasien yang dapat meningkatkan resiko kematian. Penelitian ini diperoleh $84,1 \%$ (53 pasien) memiliki tingkat komorbiditas yang sangat rendah, sedangkan hanya 2 pasien $(3,2 \%)$ memiliki tingkat komorbiditas yang tinggi. Dua pasien dengan indeks komorbid yang tinggi yaitu P65 dan P68, dimana P65 memiliki penyakit penyerta yaitu gagal jantung, edema pulmo, AKI dan epilepsi, sedangkan pada P68 memiliki penyakit penyerta spina bifida dan neurogenic bladder.

Berdasarkan uji Kruskal Wallis dalam analisis frekuensi komorbid terhadap luaran klinis pasien, didapatkan hasil nilai $\mathrm{p}=0,673$ $(p>0,05)$, sehingga dalam penelitian ini diperoleh hasil bahwa faktor komorbid pasien tidak memiliki pengaruh terhadap luaran klinis pasien. Berdasarkan hasil evaluasi variabelvariabel yang dapat beresiko atau mempengaruhi luaran klinis pasien anak dengan ISK (tabel III), diperoleh hasil analisis menggunakan uji Fisher yaitu nilai $p>0,05$ sehingga dapat diartikan dalam penelitian ini, sampel yang diujikan dengan faktor-faktor usia, jenis kelamin, status gizi dan lama perawatan tidak memiliki pengaruh terhadap luaran klinis pasien. Hasil tersebut berbeda dengan penelitian sebelumnya, bahwa faktor-faktor tersebut memberikan pengaruh terhadap luaran klinis pasien dengan ISK pada anak, hal tersebut bisa dikarenakan adanya perbedaan jumlah sampel dan tempat penelitian.
Penggunaan antibiotik empiris dalam penelitian ini terdiri dari regimen terapi tunggal dan kombinasi (tabel IV). Regimen monoterapi paling banyak digunakan yaitu 65 regimen antibiotik (92,9\%), sedangkan terapi kombinasi hanya 5 regimen antibiotik $(7,1 \%)$. Jenis antibiotik monoterapi yang paling banyak digunakan yaitu seftriakson, dengan penggunaan sebesar 20 regimen antibiotik $(28,6 \%)$, selanjutnya penggunaan antibiotik sefiksim dan ampisilin yang tidak terlampau jauh besar penggunaannya yaitu berturut-turut 14 regimen antibiotik $(20,0 \%)$ dan 13 regimen antibiotik (18,6\%). Hasil tersebut sama dengan penelitian yang dilakukan oleh Adhikary (2015) yang menemukan bahwa penggunaan antibiotik terbesar untuk ISK pada anak adalah antibiotik seftriakson $(23,94 \%)$, kemudian antibiotik sefiksim ditempat kedua $(21,12 \%)$. Sefalosporin secara umum banyak digunakan sebagai terapi ISK, seftriakson merupakan golongan sefalosporin generasi ke-3 yang efektif dalam menghambat banyak bakteri Gram negatif selain Pseudomonas spp., dan untuk switch ke oral seperti antibiotik sefiksim menjadi pilihan antibiotik oral setelah pasien pulang, karena pendosisan yang mudah (1-2 kali dosis dalam sehari) dan telah lama digunakan untuk terapi ISK simpleks pada anak (Gunduz dan Altun, 2018).

Pada penelitian ini ditemukan penggunaan antibiotik terapi kombinasi, yaitu kombinasi antibiotik ampisilin + gentamisin sebanyak 3 pasien $(4,3 \%)$. Penggunaan antibiotik kombinasi golongan penisilin dan 
Widya Adhitama, et al

Tabel IV. Karakteristik Penggunaan Antibiotik pasien ISK anak

\begin{tabular}{lr}
\hline Karakteristik & Regimen antibiotik (n= 70 regimen) n (\%) \\
\hline Penggunaan Antibiotik & \\
Monoterapi & $65(92,9)$ \\
Kombinasi & $5(7,1)$ \\
Jenis antibiotik & \\
Monoterapi & \\
Seftriakson iv. & $20(28,6)$ \\
Sefiksim po. & $14(20,0)$ \\
Ampisilin iv. & $13(18,6)$ \\
Amoksisilin po. & $5(7,1)$ \\
Sefotaksim iv. & $4(5,7)$ \\
Amikasin iv. & $3(4,3)$ \\
Gentamisin iv. & $2(2,9)$ \\
Amoksisilin-klavulanat po. & $1(1,4)$ \\
Siprofloksasin iv. & $1(1,4)$ \\
Siprofloksasin po. & $1(1,4)$ \\
Erythromisin po. & $1(1,4)$ \\
Kombinasi & \\
Ampisilin iv. + Gentamisin iv. & $3(4,3)$ \\
Amoksisilin po. + Gentamisin iv. & $1(1,4)$ \\
Sefotaksim iv. + Gentamisin iv. & $1(1,4)$ \\
Lama pemberian (hari) & \\
2 - 7 & $64(91,4)$ \\
>7 & $6(8,6)$ \\
Rute pemberian & \\
Intravena & $47(67,2)$ \\
Peroral & $22(31,4)$ \\
Intravena + peroral & $1(1,4)$ \\
\hline
\end{tabular}

aminoglikosida untuk memulai terapi ISK kompleks, secara umum kombinasi ampisilin atau sefalosporin generasi ke-3 ditambah dengan aminoglikosida seperti gentamisin sangat adekuat dalam mengeradikasi banyak uropatogen (Chang dan Shortliffe, 2006). Efek sinergis dari kombinasi penisilin dan aminoglikosida yaitu akibat kerusakan dinding sel bakteri yang dimediasi oleh penisilin, maka akan memberi jalan untuk aminoglikosida masuk ke dalam sel bakteri, sehingga keduanya merupakan kombinasi yang baik dalam melawan bakteri (Soriano dan Greenwood, 1979).

Antibiotik intravena adalah yang sering digunakan dalam terapi untuk ISK pada anak di RSUP Dr. Sardjito Yogyakarta yaitu sebesar 47 regimen terapi $(67,2 \%)$ dengan lama pemberian 2 - 7 hari $(91,4 \%)$, sesuai dengan diagnosa ISK simpleks. dalam hal ini RSUP Dr. Sardjito yang merupakan rumah sakit tipe A, maka dimungkinkan sekali pasien memiliki penyakit penyerta lain, sehingga terindikasi untuk rawat inap dan diberikan antibiotik intravena. Berdasarkan literatur durasi terapi antibiotik untuk pasien ISK simpleks yaitu pada umumnya 7 hari, namun dapat diberikan dalam waktu yang singkat 3-5 hari, sedangkan untuk pasien ISK kompleks pada anak yaitu 7-14 hari (Adhikary dkk., 2015; Pardede, 2011).

Hasil evaluasi penggunaan antibiotik empiris dengan menggunakan metode Gyssens didapatkan antibiotik yang rasional sebesar 84,3\% (59 regimen), sedangkan yang tidak rasional adalah 15,7\% (11 regimen). Dimana, data kategori yang rasional terdapat pada hampir semua jenis antibiotik yang digunakan.

Permasalahan antibiotik tidak rasional paling banyak terjadi adalah kategori III B (tabel V) yaitu sebesar 10 regimen antibiotik. Lama pemberian antibiotika untuk terapi pada ISK dipengaruhi oleh jenis penyakit dan tingkat keparahan penyakitnya. Menurut Kemenkes tahun 2011, antibiotik empiris diberikan dalam 
Tabel V.Distribusi Hasil Evaluasi Penggunaan Antibiotik Berdasarkan Metode Gyssens

\begin{tabular}{|c|c|c|c|c|}
\hline \multirow{2}{*}{ Antibiotik } & \multicolumn{3}{|c|}{ Kategori Gyssens (jumlah regimen antibiotik) } & \multirow{2}{*}{ Total } \\
\hline & $\mathbf{0}$ & II A & III B & \\
\hline \multicolumn{5}{|l|}{ Sefalosporin } \\
\hline Seftriakson iv. & 16 & 1 & 3 & 20 \\
\hline Sefiksim po. & 10 & - & 4 & 14 \\
\hline Sefotaksim iv. & 4 & - & - & 4 \\
\hline \multicolumn{5}{|l|}{ Penisilin } \\
\hline Ampisilin iv. & 11 & - & 2 & 13 \\
\hline Amoksisilin po. & 5 & - & - & 5 \\
\hline Amoksisilin-klavulanat po. & 1 & - & - & 1 \\
\hline \multicolumn{5}{|l|}{ Aminoglikosida } \\
\hline Amikasin iv. & 3 & - & - & 3 \\
\hline Gentamisin iv. & 2 & - & - & 2 \\
\hline \multicolumn{5}{|l|}{ Makrolida } \\
\hline Eritromisin po. & 1 & - & - & 1 \\
\hline \multicolumn{5}{|l|}{ Kuinolon } \\
\hline Siprofloksasin po. & 1 & - & - & 1 \\
\hline Siprofloksasin iv. & 1 & - & - & 1 \\
\hline \multicolumn{5}{|l|}{ Kombinasi } \\
\hline Ampisilin + Gentamisin & 3 & - & - & 3 \\
\hline Amoksisilin + Gentamisin & - & - & 1 & 1 \\
\hline Sefotaksim + Gentamisin & 1 & - & - & 1 \\
\hline Total & 59 & 1 & 10 & 70 \\
\hline
\end{tabular}

waktu 48-72 jam, selanjutnya dilakukan evaluasi kondisi klinis pasien serta data penunjang yang lain. Pada penelitian ini yang masuk dalam kategori III B adalah penggunaan antibiotik yang terlalu singkat, dimana kasus terbanyak yaitu hanya 2 hari, pada pasien (P5, P14, P20, P23, P32, P36, P39) dikarenakan pasien sudah mendapatkan terapi antibiotik sebelum masuk rumah sakit, namun dinyatakan pemberian antibiotik terlalu singkat karena evaluasi penggunaannya dilihat dari selama perawatan di rumah sakit saja, tanpa melihat penggunaan obat yang mungkin didapatkan dari faskes sebelumnya, sehingga ketika dalam perawatan di RSUP Dr. Sardjito kurang dari 3 hari pasien sudah mengalami perbaikan klinis dan diperbolehkan pulang.

Penggunaan antibiotik empiris yang masuk dalam kategori II A sebesar 1 regimen antibiotik. Kategori II A mengevaluasi tentang ketepatan dosis antibiotik yang digunakan, pemberian antibiotik akan memberikan efek yang maksimal apabila digunakan dengan regimen dosis antibiotik yang sesuai untuk membunuh atau menghambat pertumbuhan bakteri penyebab terjadinya infeksi. Dosis yang rasional dan dapat ditoleransi untuk diberikan kepada pasien yaitu $\pm 10 \%$ dari dosis regimen yang terhitung (McPhillips dkk., 2005). Hasil evaluasi didapatkan 1 kasus pasien (P5) dengan regimen antibiotik seftriakson $300 \mathrm{mg} / 12$ jam, berdasarkan perhitungan sesuai dalam Konsensus IDAI tahun 2011 tentang infeksi saluran kemih pada anak, dosis yang direkomendasikan untuk seftriakson yaitu 75 $\mathrm{mg} / \mathrm{kgBB} / \mathrm{hari}(\mathrm{BB}$ pasien $=3,1 \mathrm{~kg}$ ) atau 232,5 $\mathrm{mg} / 24$ jam untuk kasus pasien tersebut. Sehingga pasien menerima dosis dua kali lipat dari yang dianjurkan.

Keberhasilan suatu terapi dapat dipengaruhi oleh ketepatan dosis antibiotik yang digunakan, karena efektivitas antibiotik tersebut ditentukan oleh kadar obat di tempat aksinya. Pemberian antibiotik dengan dosis yang terlalu tinggi dapat meningkatkan resiko efek toksik yang membahayakan bagi pasien (Cipolle dkk., 1998). Selain itu, penggunaan antibiotika dengan dosis yang terlalu tinggi atau tidak tepat akan meningkatkan resiko terjadinya resistensi antibiotika (Roespandi dkk., 2007). Efek samping obat seftriakson yang dapat ditimbulkan yaitu alergi (anafilaksis, urtikaria, demam), diare, anemia (Burke dkk, 2015). Namun dalam penelitian ini, diketahui bahwa 
Widya Adhitama, et al

Tabel VI.Gambaran Pola Bakteri pada Pasien ISK Anak di RSUP Dr. Sardjito

\begin{tabular}{lcc}
\hline \multicolumn{1}{c}{ Nama bakteri } & Frekuensi (n=59) & \% \\
\hline Gram negatif & & 49,15 \\
Escherichia coli & 29 & 13,56 \\
Klebsiella pneumoniae & 8 & 6,78 \\
Pseudomonas aeruginosa & 4 & 5,08 \\
Acinetobacter lwofii & 3 & 3,39 \\
Enterobacter cloacae & 2 & 1,69 \\
Acinetobacter baumanii & 1 & 1,69 \\
Burkholderia cepacia & 1 & $\mathbf{8 1 , 3 6}$ \\
Total & $\mathbf{4 8}$ & \\
Gram positif & & 8,47 \\
Enterococcus faecalis & 5 & 5,08 \\
Staphylococcus haemoliticus & 3 & 3,39 \\
Enterococcus faecium & 2 & 1,69 \\
Staphylococcus lentus & 1 & $\mathbf{1 8 , 6 4}$ \\
Total & $\mathbf{1 1}$ &
\end{tabular}

Keterangan: $\mathrm{n}=$ jumlah bakteri yang ditemukan

belum ada intervensi dari apoteker dalam hal dosis tersebut, maka sangat dimungkinkan tidak ada percatatan mengenai ESO dalam rekam medis.

Antibiotik yang masuk dalam kategori 0 berdasarkan hasil evaluasi adalah sebesar 59 regimen antibiotik (tabel $\mathrm{V}$ ), yang paling banyak adalah seftriakson sebesar 16 regimen, diikuti ampisilin sebesar 10 regimen dan sefiksim sebesar 10 regimen. Hal ini sesuai dengan penelitian Grabe (2015), yang menyatakan bahwa antibiotik seftriakson, sefiksim (sefalosporin generasi ke-3), dan ampisilin direkomendasikan sebagai monoterapi untuk ISK pada anak.

Berdasarkan analisa uji Fisher didapatkan nilai $\mathrm{p}=0,011$ maka dapat disimpulkan bahwa pemberian antibiotik yang rasional dapat memberikan pengaruh terhadap luaran klinis pasien. Pasien yang mengalami luaran klinis membaik dengan penggunaan antibiotik empiris yang rasional yaitu $82,9 \%$, sedangkan pasien dengan luaran klinis belum membaik sebesar 1,4\%. Penggunaan antibiotik empiris yang rasional namun belum menunjukkan perbaikan klinis bisa dikarenakan resistensi antibiotik empiris yang digunakan, sehingga tidak memberikan efektivitas dalam membunuh atau menghambat bakteri penyebab infeksi pada ISK. Hasil lain yaitu pada kelompok pasien yang menggunakan antibiotik empiris tidak rasional memberikan luaran klinis membaik sebesar 11,4\%, hal tersebut dapat dikarenakan efektivitas antibiotik empiris yang digunakan dapat membunuh atau menghambat bakteri penyebab ISK.

Prediksi kadar obat antibiotik empiris dalam tubuh pada keadaan tunak dihitung berdasarkan dosis terapi yang diberikan oleh klinisi pada pasien yang menggunakan parameter farmakokinetika dari pustaka. Prediksi kadar obat dalam tubuh pada penelitian ini berdasarkan nilai MIC atau yang disebut nilai ambang efek. Jika didapatkan nilai estimasi $\mathrm{Css}^{\text {min }}$ kadar antibiotik di bawah nilai MIC maka dimungkinkan antibiotik yang digunakan tidak akan memberikan efek terapi (Hakim, 2012). Nilai MIC yang digunakan pada penelitian ini adalah nilai MIC masing-masing antibiotik berdasarkan CLSI tahun 2016.

Perhitungan prediksi kadar obat dalam tubuh pada penelitian ini dilakukan pada pasien yang mendapatkan antibiotik rasional, diperoleh hasil 26 regimen antibiotik dengan perhitungan $\mathrm{Css}^{\text {min }}<$ MIC namun memberikan luaran klinis baik, hal ini bisa dikarenakan antibiotik yang digunakan memiliki sifat post antibiotic effect (PAE) yang masih mampu memberikan efek penghambatannya meskipun kadar dalam darah kurang dari MIC. Berdasarkan hasil analisis dengan menggunakan uji Fisher, hubungan antara prediksi kadar obat terhadap luaran klinis diperoleh nilai $p=0,220$, sehingga hal ini tidak bermakna secara signifikan karena $p>0,05$, dengan demikian dalam penelitian ini dapat disimpulkan bahwa tidak terdapat hubungan antara prediksi kadar obat antibiotik empiris terhadap hasil luaran klinis pasien. Hal ini dapat 
disebabkan karena dalam penelitian ini perhitungan prediksi kadar obat dalam darah pasien menggunakan profil farmakokinetika obat berdasarkan literatur dan tidak berdasarkan pada kondisi masing-masing pasien, sehingga diasumsikan pada kondisi pasien normal.

Pada penelitian ini, ditemukan 59 spesimen urin pasien ISK, jumlah spesimen tidak sesuai dengan jumlah pasien yang dianalisis karena, pada beberapa pasien tidak ada pertumbuhan bakteri untuk hasil kulturnya. Dilihat dari tabel VI, didapatkan bakteri Gram negatif sebesar 81,36\% dan Escherichia coli merupakan bakteri terbanyak yang ditemukan yaitu sebesar 49,15\%, kemudian terbesar kedua yaitu Klebsiella pneumonia sebesar 13,56\%. Untuk bakteri Gram positif didapatkan hasil sebanyak 18,64\% dan Enterococcus faecalis yang terbanyak yaitu 8,47\%. Hasil ini sama dengan penelitian yang dilakukan oleh Syafada (2013), pada pasien ISK di Rumah Sakit X Yogyakarta didapatkan hasil biakan bakteri urin sebagian besar yaitu bakteri Gram negatif dengan persentase terbanyak bakteri Escherichia coli. Pada beberapa penelitian disebutkan bahwa secara umum bakteri patogen penyebab kejadian ISK pada anak adalah E. coli dan Klebsiella (Adhikary dkk., 2015). Hal tersebut sesuai dengan literatur yang menyatakan bahwa bakteri penyebab utama dari kasus ISK adalah bakteri Gram negatif yang merupakan bakteri dalam saluran cerna seperti E. coli, proteus, klebsiella dan enterobacter (Alpers, 2005).

Antibiotik yang paling banyak diuji sensitivitasnya pada bakteri Gram negatif adalah golongan aminoglikosida (gentamisin dan amikasin), penisilin (ampisilin sulbaktam dan ampisilin), karbapenem (meropenem) , kotrimoksazol, sefalosporin (seftazidime), kuinolon (siprofloksasin). Pada penelitian ini antibiotik yang diujikan dan paling sensitif melawan bakteri E. coli yaitu Meropenem (100\%) dan Ertapenem (96\%) dikuti oleh Amikasin (85\%).

\section{KESIMPULAN}

Penggunaan antibiotik untuk terapi empiris yang diberikan kepada pasien anak rawat inap dengan infeksi saluran kemih di RSUP Dr. Sardjito Yogyakarta yang telah dievaluasi menggunakan metode Gyssens, dari 70 regimen didapatkan 84,3\% (59 regimen antibiotik) penggunaannya rasional (kategori 0) dan 11 regimen $(15,7 \%)$ tidak rasional meliputi $14,3 \%$ (kategori IIIB), 1,4\% (kategori IIA). Penggunaan antibiotik yang rasional pada pasien rawat inap anak dengan infeksi saluran kemih di RSUP Dr. Sardjito Yogyakarta memberikan luaran klinis yang baik mencapai $82,9 \%$ dengan $\mathrm{p}<0,05$.

\section{DAFTAR PUSTAKA}

Adhikary, J., Sarmah, B.K., dan Giri, A., 2015. Analysis of Prescribing Pattern of Antibiotics in Paediatric Urinary Tract Infection at A Teaching Hospital, International Journal of Contemporary Medical Research, 4: 3.

Alpers, C. E., 2005, Ginjal, dalam Kumar, V., (Ed.), Robbins \& Contran Pathologic Basic of Disease, th 7 Edition, diterjemahkan oleh Luaman, Y. R., Frans D., Leo, R., (editor), EGC, Jakarta, 1017

Burke, K., Hoffman, J., Nemerovski, C., Sklar, S., Stout, S.M., Streetman, D., Weinstein, D.M., 2015, Drug Information Handbook, 24th Ed, Lexi-Comp for the American Pharmacists Association

Chang, S.L. dan Shortliffe, L.D., 2006. Pediatric Urinary Tract Infections. Pediatric Clinics of North America, 53: 379-400.

Cipolle, R.J, Strand, L.M. \& Morley, P.C., 1998, Pharmaceutical Care Practice, 75, 82-83, Mc Graw Hill Company, New York.

Coyle, E.A., and Prince, R.A., 2008, Pharmacotherapy: A Pathophysiologic Approach. McGraw-Hill, New York, 20812095

Dahlan, M.S, 2016, Besar Sampel dan Cara Pengambilan Sampel Dalam Penelitian Kedokteran dan Kesehatan, edisi 4, Salemba Medika, Jakarta

Grabe, M., Bartoletti, R., Johansen, T.E.B., Cai, T., Cek, M., Koves, B., et al. 2015, Guidelines on Urological Infections, European Association of Urology, 33-39

Gunduz, S., dan Altun, H.U., 2018, Antibiotic Resistance Patterns of Urinary Tract Pathogens in Turkish Children, Global Health Research and Policy, 3: 1-5

Hakim, L., 2012, Farmakokinetika Klinik, Konsep Dasar dan Terapan dalam Farmasi Klinik, Bursa Ilmu, Yogyakarta, 64-78

Kementrian Kesehatan, 2011, Pedoman Pelayanan Kefarmasian Untuk Terapi Antibiotik, Jakarta, Kementerian Kesehatan Republik Indonesia. 
Widya Adhitama, et al

McPhillips, H.A., Stille, C.J., Smith, D., Hecht, J., Pearson, J., Stull, J., dkk., 2005. Potential Medication Dosing Errors in Outpatient Pediatrics. The Journal of Pediatrics, 147: 761-767.

Newman, D.H., Shreves, A.E., dan Runde, D.P., 2013. Pediatric Urinary Tract Infection: Does the Evidence Support Aggressively Pursuing the Diagnosis? Annals of Emergency Medicine, 61: 559-565.

Okarska-Napierała, M., Wasilewska, A., dan Kuchar, E., 2017. Urinary tract infection in children: Diagnosis, treatment, imaging Comparison of current guidelines. Journal of Pediatric Urology, 13: 567-573.

Pardede, S.O., Tambunan, T., Alatas, H., Trihono, P.P., Hidayati, E.L., 2011, Konsensus Infeksi Saluran Kemih Pada Anak, Ikatan Dokter Anak Indonesia (IDAI), Jakarta

Roespandi, H., Nurhamzah, W., Ainy, S. N. 2007, Buku Saku Pelayanan Kesehatan Anak di Rumah Sakit, Departemen Kesehatan Republik Indonesia, Jakarta, 167-168

Rosli, A. W., dkk., 2008, Relationship between protein energy malnutrition and urinary tract infection in chlidren, Paeditrica Indonesiana, 48: 166-169

Soriano, F. dan Greenwood, D., 1979. Action and interaction of penicillin and gentamicin on enterococci. Journal of Clinical Pathology, 32: 1174-1179.

Syafada dan Fenty, 2013, Pola Kuman dan Sensitivitas Antimikroba Pada Infeksi Saluran Kemih, Jurnal Farmasi Sains dan Komunitas, 10:9-13

Torres-Espíndola, L.M., Demetrio-Ríos, J., Carmona-Aparicio, L., Galván-Díaz, C., Pérez-García, M., Chávez-Pacheco, J.L., dkk., 2019. Comorbidity Index as a Predictor of Mortality in Pediatric Patients with Solid Tumors. Frontiers in Pediatrics, 7: 1-7

Triasta, Djatnika Setiabudi, Dedi Rachmadi, 2016, Faktor Risiko Kecurigaan Infeksi Saluran Kemih pada Anak Laki-laki Usia Sekolah Dasar, Sari Pediatri, 18: 137-141

World Health Organization (Editor), 2013. Pocket Book of Hospital Care for Children: Guidelines for the Management of Common Childhood Illnesses, Second edition, 2013 edition. ed. World Health Organization, Geneva, Switzerland.

Yunita, T., 2017, Evaluasi Rasionalitas Penggunaan Antibiotik Pasien Infeksi Saluran Kemih Pediatrik di Instalasi Rawat Inap RS Bethesda Yogyakarta tahun 2015, Skripsi, S.Farm., Fakultas Farmasi, Universitas Sanata Dharma, Yogyakarta 